\title{
Replacement of aruana grass by gliricidia (Gliricidia sepium) on silage quality
}

\author{
Danilo Antonio Massafera1, Ligiane Aparecida Florentino², Carlos Henrique Silveira Rabelo², \\ Carla Joice Härter ${ }^{4}$, Adauton Vilela de Rezende ${ }^{2}$, Ricardo Andrade Reis ${ }^{4}$
}

\author{
1 Universidade José do Rosário Vellano, Programa de Pós-graduação em Ciência Animal, Alfenas, MG, Brasil. \\ 2 Universidade José do Rosário Vellano, Departamento de Agronomia, Alfenas, MG, Brasil. \\ ${ }^{3}$ Universidade Estadual Paulista, Programa de Pós-graduação em Zootecnia, Jaboticabal, SP, Brasil. \\ ${ }^{4}$ Universidade Estadual Paulista, Departamento de Zootecnia, Jaboticabal, SP, Brasil.
}

\begin{abstract}
Our objective was to investigate the effect of the replacement of aruana grass by gliricidia on the fermentative losses, chemical composition, and aerobic stability of silages. For ensiling, whole-crop aruana grass (75 d of growth) was chopped (275 $\mathrm{g} \mathrm{kg}^{-1}$ dry matter - DM) and ensiled alone or associated with gliricidia $\left(270 \mathrm{~g} \mathrm{~kg}^{-1} \mathrm{DM} ; 150 \mathrm{~d}\right.$ of growth). For gliricidia, we used only the leaves and stalks to ensile. The evaluated treatments were different ratios of aruana grass to gliricidia (100:0, 75:25, 50:50, 25:75, and 0:100), with four replicates (mini-silos). The silage composed only of gliricidia exhibited a lower $\mathrm{pH}$ than the other silages. Dry matter recovery was not affected by the treatments, although effluent losses were affected. The replacement of aruana grass by gliricidia $50 \%$ at ensiling resulted in a higher lactic acid bacteria count. The aruana grass silages displayed lower protein contents and a higher neutral detergent fiber content than the gliricidia silages after $40 \mathrm{~d}$ of fermentation. Consequently, the silage consisting of $100 \%$ gliricidia showed higher in vitro DM digestibility, presenting an increase of $8.13 \%$ after $40 \mathrm{~d}$ of fermentation compared with $100 \%$ of aruana grass silage. After silo opening, the gliricidia silage was very stable $(>72 \mathrm{~h})$. The low quality of aruana grass silage is improved by replacing this grass with significant amounts of gliricidia (approximately $75 \%$ ).
\end{abstract}

Key Words: digestibility, fermentative process, fiber, legumes, tropical grass

\section{Introduction}

Aruana grass is a species of the genus Panicum maximum used mainly as pasture in Brazil (Gerdes et al., 2005) that exhibits high productivity throughout the year, mainly in the summer (Pompeu et al., 2010). During the dry season, there is a shortage of animal feed, and an alternative is to harvest the excess forage from the rainy season for use as silage during this period. Grass silages are among the most widely used types of roughage in Brazilian beef cattle feedlots and for dairy cows (Millen et al., 2009; Costa et al., 2013). However, it is difficult to ensure good silage quality using only tropical grasses because these forages usually exhibit a low amount of water-soluble carbohydrates (WSC), a high buffering capacity, low lactic acid bacteria (LAB) count, and low dry matter (DM) and protein contents at cutting (McDonald et al., 1991; Bergamaschine et al., 2006; Keady et al., 2008).

Received October 23, 2014 and accepted May 31, 2015

Corresponding author: carlos.zoo@hotmail.com

http://dx.doi.org/10.1590/S1806-92902015000700001

Copyright (c) 2015 Sociedade Brasileira de Zootecnia. This is an Open Access article distributed under the terms of the Creative Commons Attribution Non-Commercial License, which permits unrestricted non-commercial use, distribution, and reproduction in any medium, provided the original work is properly cited.
As an alternative to overcome these problems, some legumes can be used to improve the silage quality of grasses by increasing the protein and WSC contents (Copani et al., 2014) and reducing the costs associated with traditional protein sources in animal nutrition (e.g., soybean) (Santos et al., 2009). Gliricidia (Gliricidia sepium) is a tropical tree legume that has been widely employed as plantation shade, green manure, living fence posts, firewood, and livestock fodder (Simons and Stewart, 1994). However, in some regions, particularly in tropical countries, gliricidia has been used during ensiling, and after wilting, because this legume can improve fermentation in silages (Tjandraatmadja et al., 1993a,b; Cabral Jr. et al., 2007). The quality of corn, pangola grass, and setaria silage is improved by the addition of gliricidia (Tjandraatmadja et al., 1994; Kato et al., 2006), presumably leading to superior animal performance (Costa et al., 2007).

Conversely, silages resulting from a good fermentation (particularly greater production of lactic acid) exhibit low aerobic stability after silo opening (Filya, 2003) because the lactic acid per se has no antifungal properties (Moon, 1983). Thus, yeasts and molds possibly have a greater action on these silages, causing mass spoilage and increasing DM and energy losses, and consequently reducing the nutritive value of the silage (Wilkinson and Davies, 2012). 
Therefore, our objective was to investigate the effect of the replacement of aruana grass by gliricidia on the fermentative losses, chemical composition, and aerobic stability of silages.

\section{Material and Methods}

This study was conducted in a tropical savanna with hot summers (AWA), characterized as having a tropical wet and dry climate (rainy in the summer and dry in the winter), according to the Köppen classification. The gliricidia was sown and cultivated following the descriptions of Rangel et al. (2011). At $75 \mathrm{~d}$ after gliricidia was sown, aruana grass was sown using $450 \mathrm{~kg}$ of $\mathrm{P}_{2} \mathrm{O}_{5}$. Forty days later, we performed the first application of urea (topdressing), and after 30 and $60 \mathrm{~d}$, we performed two additional urea applications, for a total of $150 \mathrm{~kg}^{\mathrm{urea} \mathrm{ha}} \mathrm{h}^{-1}$.

The gliricidia and aruana grass were harvested at 150 and $75 \mathrm{~d}$ of growth, respectively. For gliricidia, we harvested only the leaves and stalks with a diameter of less than $1 \mathrm{~cm}$, whereas aruana grass was harvested by cutting the plants $20 \mathrm{~cm}$ above the soil surface. Gliricidia was allowed to wilt under the sun for $24 \mathrm{~h}$, as recommended by Cabral Jr. et al. (2007). Both forages were chopped to achieve a theoretical length of $20 \mathrm{~mm}$ and ensiled with approximately $270 \mathrm{~g} \mathrm{~kg}^{-1}$ DM (Table 1). The evaluated treatments were different ratios of aruana grass to gliricidia (100:0, 75:25, 50:50, $25: 75$, and $0: 100$ ). The proportions were based on the fresh matter.

Polyvinyl chloride (PVC) tubes with a 5-L capacity were used as the experimental silos, which remained closed for $40 \mathrm{~d}$. The experimental silos were weighed after filling and at the end of the ensiling period to determine the effluent, gas, and DM losses according to equations proposed by Jobim et al. (2007).

After opening the silos, the aerobic stability was determined by placing $4 \mathrm{~kg}$ of the silages in buckets. The temperature of the silage was measured every $6 \mathrm{~h}$ during the 3-d period of aerobic exposure using a thermometer placed in the center of the mass. The buckets were placed in a room that was maintained at ambient temperature, and the aerobic stability was defined as the length of time required to increase the temperature of silages to $2{ }^{\circ} \mathrm{C}$ above the ambient temperature (Kung et al., 2007). Additionally, the heating rate, which was calculated as the maximum recorded temperature divided by the time needed to reach the maximum temperature, was evaluated (Ruppel et al., 1995). During aerobic exposure, we also determined the $\mathrm{pH}$ values in the silages using the same buckets while measuring the temperature (approximately $20 \mathrm{~g}$ of silage was sampled in each time). The data on maximum temperature and maximum $\mathrm{pH}$ describe only the maximum temperature and maximum $\mathrm{pH}$ values observed during the $3 \mathrm{~d}$ of aerobic exposure for each treatment. Additionally, the yeasts, molds, LAB, and total bacteria present in the silages were also evaluated.

For the microbiological analyses, initially a silage sample of $25 \mathrm{~g}$ from each replicate was homogenized in $225 \mathrm{~mL}$ of saline solution $(\mathrm{NaCl} 0.85 \%)$ for 1 min. Afterwards, we used $10 \%$ of the mix described earlier to provide the microorganism count assuming higher homogenization of the process. Then, we transferred $1 \mathrm{~mL}$ of this solution to tubes with $9 \mathrm{~mL}$ of saline solution, and $1 \mathrm{~mL}$ of this mixture was plated on Petri plates at dilutions of $10^{-1}$ to $10^{-9}$. Nutrient agar was used to count the total microorganisms present; Rogosa agar was used to count Lactobacilli; BDA agar was used to count yeasts and molds; and Violeta Red Bile agar was used to count enterobacteria. The BDA agar plates were incubated at $36^{\circ} \mathrm{C}$, whereas the other plates were incubated at $35.5^{\circ} \mathrm{C}$ for $2 \mathrm{~d}$. All of the microbiological data were $\log$ transformed.

For $\mathrm{pH}$ evaluation, water extracts were obtained according to Kung et al. (1984). The $\mathrm{pH}$ was determined using a pH meter (MA522 model, Marconi Laboratory Equipment, Piracicaba, Brazil). Silage samples were dried in a heated oven with forced-air ventilation $\left(55^{\circ} \mathrm{C}\right.$ for $\left.72 \mathrm{~h}\right)$, processed in a Wiley mill through a $1-\mathrm{mm}$ screen sieve, and the DM content was determined $\left(105^{\circ} \mathrm{C}\right.$ for $\left.12 \mathrm{~h}\right)$. The total nitrogen (TN) content was determined according to AOAC (1996, method 954.01). The crude protein (CP) content was determined by multiplying TN by 6.25 . The neutral detergent fiber (NDF) and acid detergent fiber (ADF)

Table 1 - Chemical composition ( $\left.\mathrm{g} \mathrm{kg}^{-1} \mathrm{DM}\right)$ of aruana grass and gliricidia, either alone or in mixtures before ensiling

\begin{tabular}{|c|c|c|c|c|c|c|c|}
\hline \multirow[b]{2}{*}{ Item } & \multicolumn{5}{|c|}{ Aruana grass replaced by gliricidia, $\%$} & \multirow[b]{2}{*}{ SEM $^{1}$} & \multirow[b]{2}{*}{ P-value } \\
\hline & 0 & 25 & 50 & 75 & 100 & & \\
\hline Dry matter, $\mathrm{g} \mathrm{kg}^{-1}$ as fed & 275.36 & 278.77 & 270.99 & 271.43 & 270.51 & 2.06 & 0.0680 \\
\hline Crude protein & 92.67 & 97.63 & 109.14 & 114.77 & 110.65 & 5.94 & 0.0877 \\
\hline
\end{tabular}

${ }^{1}$ The standard errors of the least squares means and P-values represent the statistical comparisons among the treatments. 
contents were determined sequentially using the method of Van Soest et al. (1991) without heat-stable $\alpha$-amylase and sodium sulfite.

For the in vitro digestibility, we used rumen fluid from a ruminally cannulated bull that was fed aruana and gliricidia silages (50:50 ratio, as-is fresh matter basis) for $15 \mathrm{~d}$. After adaptation, the rumen fluid was collected in the morning before feeding and filtered through four layers of cheesecloth into pre-warmed thermos flasks, then homogenized and mixed with buffer solution ("synthetic saliva") at a ratio of 4:1. Posteriorly, the coefficient of in vitro dry matter digestibility (IVDMD) was determined according to Tilley and Terry (1963). Humane animal care and handling procedures were followed according to the Animal Care Committee of Universidade José do Rosário Vellano.

The experiment was organized in a completely randomized design with four replicates. The microbial profile, chemical composition, fermentative losses, digestibility, maximum temperature, maximum $\mathrm{pH}$, heating rate, and aerobic stability data were analyzed with a mixed model using the MIXED procedure of SAS (Statistical Analysis System, version 9.2.), considering aruana grass replaced by gliricidia as a fixed effect and the residual error as a random effect. Differences between the means were determined using the DIFF option of the LSMEANS statement, which differentiates the means based on Fisher's F-protected least significant difference test. The following general model was used:

$$
\mathrm{Y}_{i j}=\mu+\mathrm{G}_{i}+\mathrm{e}_{i j}
$$

in which $\mathrm{Y}_{i j}=$ response variable; $\mu$ = overall mean; $\mathrm{G}=$ effect of aruana grass replaced by gliricidia $i$; and $\mathrm{e}_{i j}=$ error term.

Contrasts were constructed, and the single degreeof-freedom orthogonal comparisons included the linear, quadratic, and cubic effects of the aruana grass replaced by gliricidia. The differences were declared significant at $\mathrm{P} \leq 0.05$. Through the equations obtained from contrasts, we estimated the minimum and maximum values for each variable and the replacement of aruana grass by gliricidia required to achieve it. Since there were significant differences between treatments $(\mathrm{P} \leq 0.05)$, based on estimations and mean comparisons, we only attributed a positive or negative factor for aruana grass and gliricidia.

The temperature, $\mathrm{pH}$, and microbial occurrence data over the $3 \mathrm{~d}$ were analyzed as a completely randomized design with repeated measures over time. The following general model was used:

$$
\mathrm{Y}_{i j k}=\mu+\mathrm{G}_{i}+\mathrm{T}_{j}+\mathrm{GT}_{i j}+\mathrm{e}_{i j k},
$$

in which $\mathrm{Y}_{i j k}=$ response variable; $\mu=$ overall mean; $\mathrm{G}=$ effect of aruana grass replaced by gliricidia $i$; $=$ effect of time $j ; \mathrm{GT}=$ effect of the interaction between the gliricidia level $i$ and time $j$; and $\mathrm{e}_{i j k}=$ error term.

Various error covariance structures were investigated, and the structure that best fit the data according to the Bayesian information criterion (BIC) was selected. The VC covariance structure was selected for the temperature and $\mathrm{pH}$. Differences were considered significant at $\mathrm{P}<0.05$.

\section{Results}

The DM and CP contents and $\mathrm{pH}$ values were evaluated before ensiling. Treatments had no influence on DM or CP contents $(\mathrm{P}>0.05)$, which had an overall mean of $273.4 \mathrm{~g} \mathrm{~kg}^{-1}$ as fed and $104.9 \mathrm{~g} \mathrm{~kg}^{-1} \mathrm{DM}$, respectively. For $\mathrm{pH}$, the mixture of aruana grass and gliricidia (irrespective of the ratio) decreased the $\mathrm{pH}(\mathrm{P}<0.01$; Table 1$)$.

At silo opening, the occurrence of LAB showed a quadratic response, and the largest population was obtained when $50 \%$ of aruana grass was replaced by gliricidia $(\mathrm{P}<0.01)$. However, the occurrence of yeasts, molds, and total bacteria showed a cubic response $(\mathrm{P}<0.01)$. The lowest population of yeasts was observed with the replacement of $50 \%$ aruana grass, whereas the population of total bacteria increased when 50 and $100 \%$ of aruana grass were replaced by gliricidia (Table 2 ).

The replacement of aruana grass by gliricidia caused a quadratic reduction on the $\mathrm{pH}$ values of the silages $(\mathrm{P}<0.01)$, resulting in a lower value when aruana grass was replaced by gliricidia from 50 to $100 \%$. However, this response did not interfere with gas losses or DM recovery $(\mathrm{P}>0.05)$, although the effluent losses increased when aruana grass was replaced by gliricidia regardless of the ratio $(\mathrm{P}<0.05$; Table 2$)$.

The DM content was changed by the treatments, showing a cubic response $(\mathrm{P}<0.01)$, and the replacement of aruana grass by 75 and $100 \%$ of gliricidia led to lower values. We also detected a linear increase in the CP content with the replacement of aruana grass by gliricidia $(\mathrm{P}<0.01)$. Comparing the silages exclusively composed of aruana grass or gliricidia, the CP content was $43.30 \%$ higher for the gliricidia silage (Table 2).

In contrast, there was a linear decrease in the NDF content with the replacement of aruana grass by gliricidia $(\mathrm{P}<0.01)$. The gliricidia silage displayed a $41.23 \%$ lower NDF content than the aruana grass silage $\left(671.42 \mathrm{~g} \mathrm{~kg}^{-1}\right.$ DM). Similarly, the ADF content decreased quadratically when the aruana grass was replaced by gliricidia $(\mathrm{P}<0.01)$, and the lowest values were observed for 75 and $100 \%$ of replacement. In response, the replacement of aruana grass by gliricidia increased the IVDMD coefficients of the silages linearly $(\mathrm{P}<0.01$; Table 2$)$. 
The temperatures of the silages at silo opening were not changed by the treatments $(\mathrm{P}>0.05)$. However, the maximum temperature and $\mathrm{pH}$ showed a quadratic response, and the lowest values were obtained with the exclusive ensiling of gliricidia $(\mathrm{P}<0.01)$. The heating rate was also not affected $(\mathrm{P}>0.05)$, whereas the aerobic stability showed a cubic response $(\mathrm{P}<0.01$; Table 2$)$, in which the ensiling of gliricidia exclusively displayed the highest value $(>72 \mathrm{~h})$.

Through the equations obtained from contrasts, we estimated at which level aruana grass should be replaced by gliricidia to improve the silage quality based on each variable (Table 3). Overall, the estimations suggest that

Table 2 - Fermentative losses, chemical composition, microorganism profile, and aerobic stability of silages composed of aruana and gliricidia, either alone or in mixtures

\begin{tabular}{|c|c|c|c|c|c|c|c|c|}
\hline \multirow[b]{2}{*}{ Item } & \multicolumn{5}{|c|}{ Aruana grass replaced by gliricidia, $\%$} & \multirow[b]{2}{*}{$\mathrm{SEM}^{1}$} & \multirow[b]{2}{*}{ P-value } & \multirow[b]{2}{*}{ Contras } \\
\hline & 0 & 25 & 50 & 75 & 100 & & & \\
\hline \multicolumn{9}{|l|}{ Microbiology, $\log _{10} \mathrm{cfu} \mathrm{g}^{-1}$} \\
\hline Lactic acid bacteria & 7.81 & 8.38 & 9.16 & 8.29 & 7.77 & 0.04 & $<0.0001$ & $\mathrm{Q}^{* *}$ \\
\hline Yeasts and molds & 7.50 & 8.38 & 6.66 & 7.08 & 8.29 & 0.03 & $<0.0001$ & $\mathrm{C}^{* *}$ \\
\hline Total bacteria & 7.51 & 8.09 & 8.45 & 7.02 & 8.41 & 0.03 & $<0.0001$ & $\mathrm{C}^{* *}$ \\
\hline \multicolumn{9}{|l|}{ Fermentation and losses } \\
\hline $\mathrm{pH}$ & 5.76 & 5.35 & 5.00 & 4.90 & 4.86 & 0.10 & 0.0002 & $\mathrm{Q}^{*}$ \\
\hline Effluent, $\mathrm{kg} \mathrm{t}^{-1}$ fresh silage & 35.76 & 78.36 & 74.90 & 76.90 & 64.55 & 8.30 & 0.0127 & $\mathrm{Q}^{*}$ \\
\hline Gas, $\mathrm{g} \mathrm{kg}^{-1} \mathrm{DM}$ & 4.22 & 4.26 & 4.27 & 4.51 & 3.89 & 0.87 & 0.9913 & ns \\
\hline $\mathrm{DM}$ recovery, $\mathrm{g} \mathrm{kg}^{-1} \mathrm{DM}$ & 855.62 & 811.85 & 822.51 & 810.00 & 845.26 & 34.77 & 0.8432 & ns \\
\hline \multicolumn{9}{|l|}{ Chemical composition, $\mathrm{g} \mathrm{kg}^{-1} \mathrm{DM}$} \\
\hline $\mathrm{DM}, \mathrm{g} \mathrm{kg}^{-1}$ as fed & 281.55 & 282.47 & 280.82 & 274.54 & 275.93 & 1.28 & 0.0013 & $\mathrm{C}^{*}$ \\
\hline $\mathrm{CP}$ & 89.53 & 100.67 & 110.58 & 119.96 & 128.30 & 3.84 & $<0.0001$ & $\mathrm{~L}^{* *}$ \\
\hline NDF & 671.42 & 609.40 & 537.40 & 465.38 & 394.60 & 11.46 & $<0.0001$ & $\mathrm{~L}^{* *}$ \\
\hline $\mathrm{ADF}$ & 413.20 & 400.58 & 372.38 & 303.71 & 256.39 & 6.33 & $<0.0001$ & $\mathrm{Q}^{*}$ \\
\hline IVDMD & 573.11 & 576.20 & 598.58 & 605.26 & 619.70 & 4.97 & $<0.0001$ & $\mathrm{~L}^{* *}$ \\
\hline \multicolumn{9}{|l|}{ Aerobic exposure period } \\
\hline Initial temperature, ${ }^{\circ} \mathrm{C}$ & 18.00 & 18.50 & 18.50 & 18.00 & 18.25 & 0.21 & 0.2930 & ns \\
\hline Maximum temperature, ${ }^{\circ} \mathrm{C}$ & 20.00 & 20.00 & 20.00 & 20.00 & 19.25 & 0.11 & 0.0006 & $\mathrm{Q}^{*}$ \\
\hline Heating hate, ${ }^{\circ} \mathrm{C}^{-1}$ & 0.19 & 0.22 & 0.15 & 0.05 & 0.05 & 0.06 & 0.2225 & ns \\
\hline Maximum $\mathrm{pH}$ & 5.57 & 5.56 & 5.47 & 5.28 & 5.14 & 0.04 & $<0.0001$ & $\mathrm{Q}^{*}$ \\
\hline Aerobic stability, h & 42.0 & 42.0 & 22.5 & 42.0 & 72.0 & 2.97 & $<0.0001$ & $\mathrm{C}^{*}$ \\
\hline
\end{tabular}

DM - dry matter; CP - crude protein; NDF - neutral detergent fiber; ADF - acid detergent fiber; IVDMD - in vitro dry matter digestibility

$\mathrm{L}$ - linear; $\mathrm{Q}$ - quadratic; $\mathrm{C}$ - cubic; ns - not significant. * $\mathrm{P}<0.05 ; * * \mathrm{P}<0.01$

${ }^{1}$ The standard errors of the least squares means and $\mathrm{P}$-values represent the statistical comparisons among the silages.

Table 3 - Response factor and minimum and maximum values for the aruana grass silages with replacement by gliricidia

\begin{tabular}{|c|c|c|c|c|c|c|}
\hline \multirow[b]{2}{*}{ Item } & \multicolumn{2}{|c|}{ Response factor } & \multicolumn{4}{|c|}{ Values } \\
\hline & Aruana grass & Gliricidia & Minimum & $\%$ Gliricidia & Maximum & $\%$ Gliricidia \\
\hline \multicolumn{7}{|l|}{ Microbiology, $\log _{10} \mathrm{cfu} \mathrm{g}^{-1}$} \\
\hline Lactic acid bacteria & - & + & 7.66 & 0.0 & 8.86 & 52.2 \\
\hline Yeasts and molds & + & - & 6.04 & 71.2 & 7.94 & 100.0 \\
\hline Total bacteria & - & + & 7.35 & 10.5 & 10.14 & 92.7 \\
\hline \multicolumn{7}{|l|}{ Fermentation and losses } \\
\hline $\mathrm{pH}$ & - & + & 4.78 & 76.0 & 5.68 & 0.0 \\
\hline Effluent, $\mathrm{kg} \mathrm{t}^{-1}$ fresh silage & + & - & 40.71 & 0.0 & 85.76 & 58.4 \\
\hline Gas, $\mathrm{g} \mathrm{kg}^{-1} \mathrm{DM}$ & - & + & 3.89 & 100.0 & 4.51 & 75.0 \\
\hline DM recovery, $\mathrm{g} \mathrm{kg}^{-1} \mathrm{DM}$ & + & - & 810.00 & 75.0 & 855.62 & 0.0 \\
\hline \multicolumn{7}{|l|}{ Chemical composition, $\mathrm{g} \mathrm{kg}^{-1} \mathrm{DM}$} \\
\hline $\mathrm{DM}, \mathrm{g} \mathrm{kg}^{-1}$ as fed & - & - & 275.90 & 100.0 & 282.22 & 69.6 \\
\hline $\mathrm{CP}$ & - & + & 96.50 & 0.0 & 129.78 & 100.0 \\
\hline NDF & - & + & 631.64 & 0.0 & 388.24 & 100.0 \\
\hline $\mathrm{ADF}$ & - & + & 264.17 & 100.0 & 400.82 & 0.0 \\
\hline IVDMD & - & + & 577.03 & 0.0 & 620.88 & 100.0 \\
\hline \multicolumn{7}{|l|}{ Aerobic exposure period } \\
\hline Initial temperature, ${ }^{\circ} \mathrm{C}$ & + & + & 18.00 & $0.0 / 75.0$ & 18.50 & $25.0 / 50.0$ \\
\hline Maximum temperature, ${ }^{\circ} \mathrm{C}$ & - & + & 19.27 & 100.0 & 20.04 & 24.9 \\
\hline Heating hate, ${ }^{\circ} \mathrm{C} \mathrm{h}^{-1}$ & - & + & 0.05 & $75.0 / 100.0$ & 0.22 & 25.0 \\
\hline Maximum $\mathrm{pH}$ & - & + & 5.15 & 100.0 & 5.53 & 0.0 \\
\hline Aerobic stability, h & - & - & 16.73 & 65.0 & 72.00 & 100.0 \\
\hline
\end{tabular}

DM - dry matter; CP - crude protein; NDF - neutral detergent fiber; ADF - acid detergent fiber; IVDMD - in vitro dry matter digestibility. 
a minimum of $52.2 \%$ replacement of aruana grass by gliricidia should be enough to improve the silage quality, but values close to $100 \%$ are more desirable considering higher coefficients of in vitro digestibility and aerobic stability. Likewise, the replacement of aruana grass by gliricidia had a positive response on the populations of LAB and total bacteria, silage $\mathrm{pH}$, protein, fiber, and digestibility, as well as on the aerobic stability of silages.

During the aerobic exposure, the occurrence of LAB and total bacteria showed a wide range $(\mathrm{P}<0.01)$, whereas the populations of yeasts and molds presented a tendency to increase $(\mathrm{P}<0.01$; Figure 1$)$. As expected, the temperature of the silages increased during the aerobic phase $(\mathrm{P}<0.01)$, but this increase was not greater than $2{ }^{\circ} \mathrm{C}$ within each treatment (Figure 2). For the $\mathrm{pH}$, silages containing 75 and $100 \%$ of gliricidia showed lower values $(\mathrm{P}<0.01)$ during aerobic exposure (Figure 2).
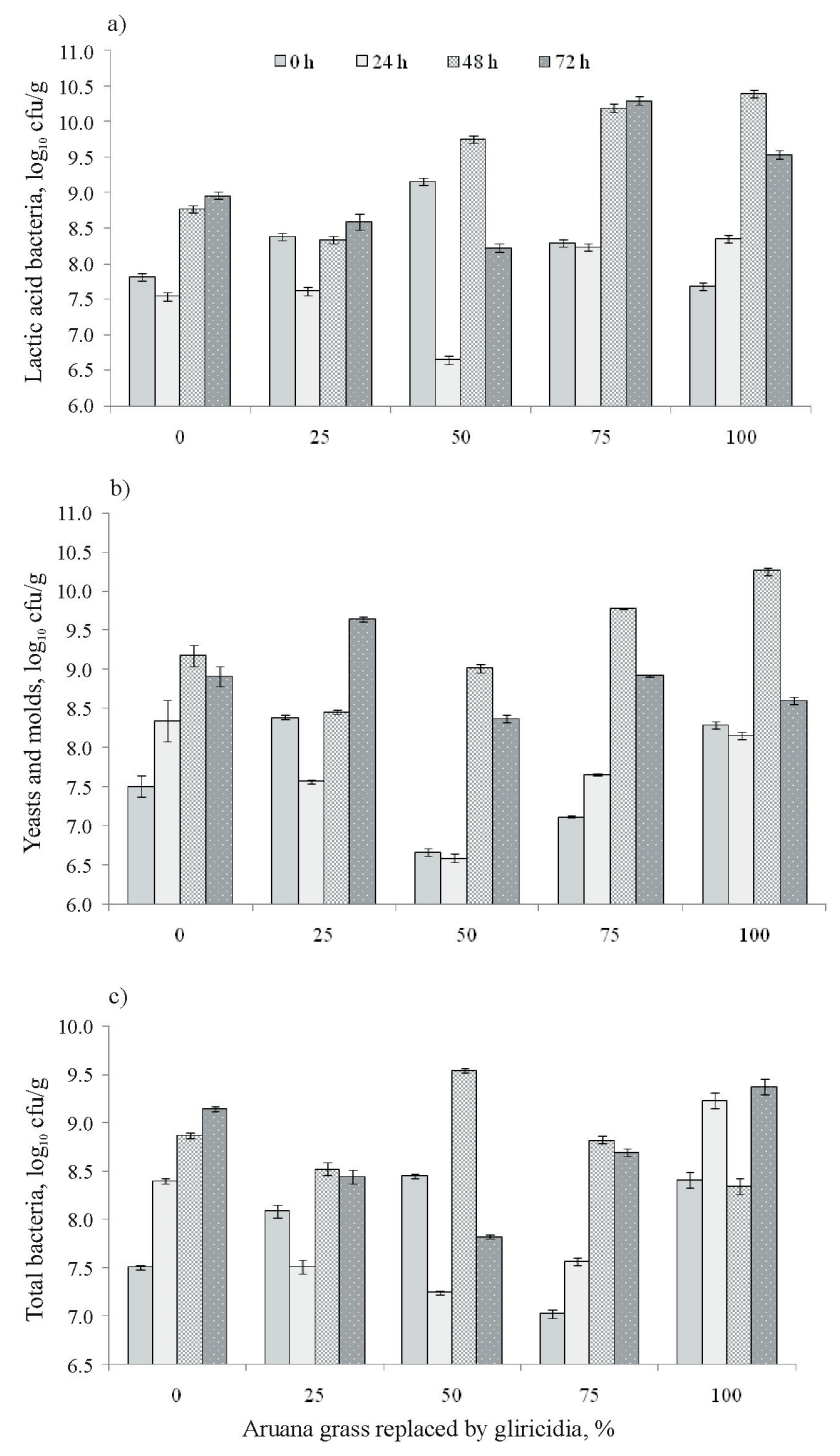

Figure 1 - Occurrence of LAB (a), yeasts and molds (b), and total bacteria (c) in the silages during aerobic exposure.
As described earlier, the silage composed of gliricidia only exhibited greater aerobic stability (Table 2). However, all of the silages showed relatively constant temperatures during oxygen exposure. In contrast, the aerobic stability assay was conducted under ambient conditions, which presented a wide range during the aerobic exposure period; this was the main factor to promote stability breaking (Figure 3).
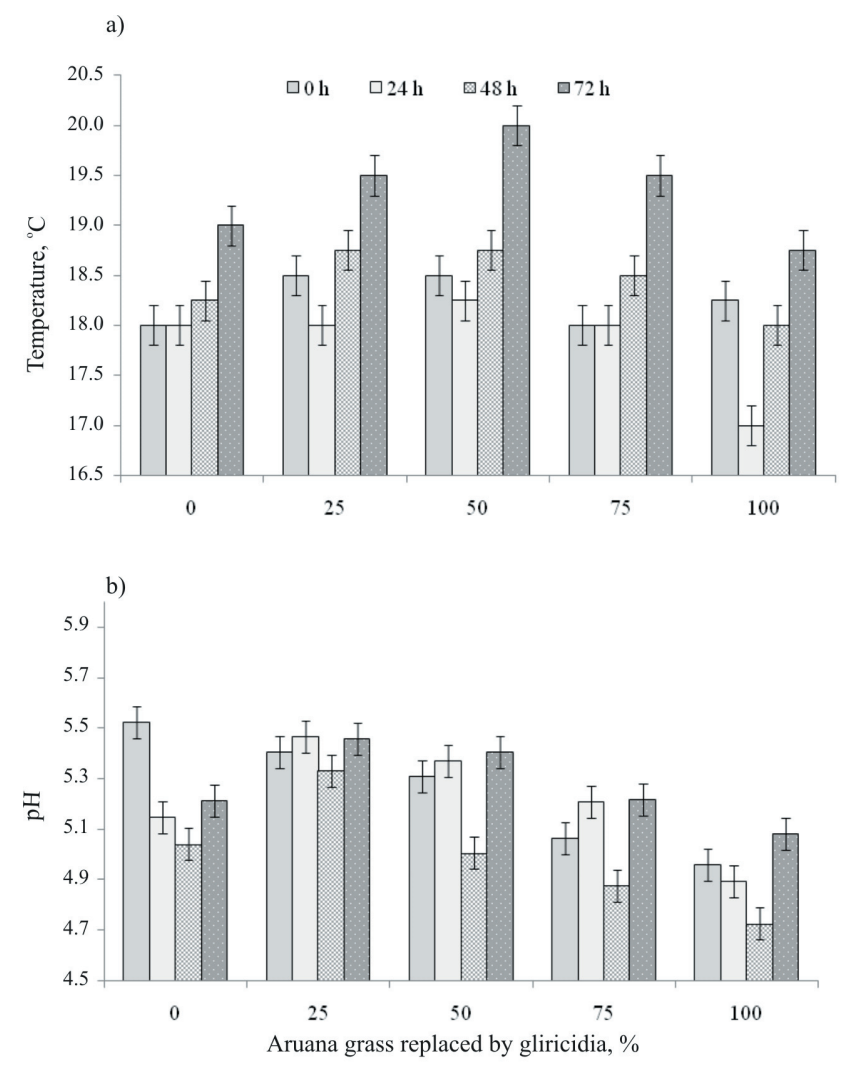

Figure 2 - Temperature (a) and $\mathrm{pH}$ values (b) of the silages during aerobic exposure.

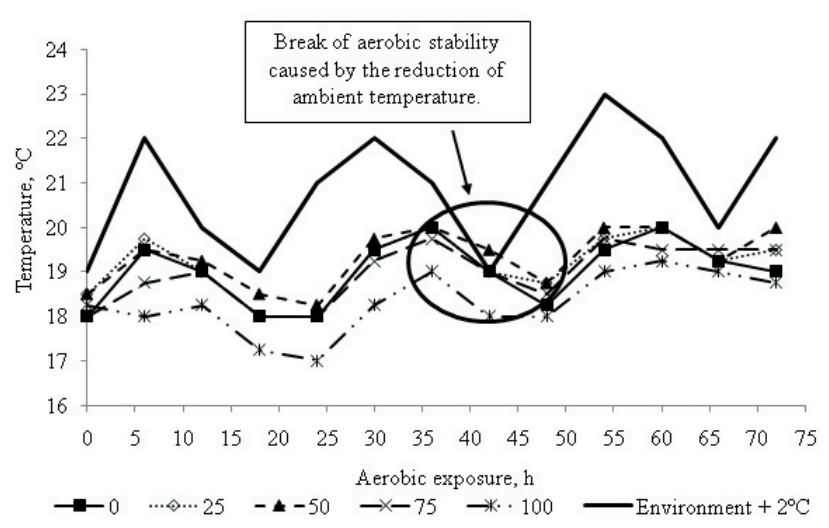

Figure 3 - Temperature behavior of the silages during aerobic exposure (aruana grass replaced by gliricidia at a rate of $0,25,50,75$, or $100 \%)$. 


\section{Discussion}

The ensilage of aruana grass with $50 \%$ of gliricidia resulted in greater $\mathrm{LAB}$ counts after $40 \mathrm{~d}$ of fermentation. As is well known, LAB are the main group of microorganisms found in silage and are more desirable to promote good fermentation (Muck, 2010). Theoretically, LAB must extensively ferment forages containing high contents of WSC, resulting in greater production of organic acids, mainly lactic acid, which reduces $\mathrm{pH}$ values, ensuring the nutritive value of the silage (McDonald et al., 1991). As expected, the replacement of aruana grass by gliricidia increased the $\mathrm{CP}$ content. Although the high protein content may increase the buffering capacity of the silage, in the present study, we observed a lower $\mathrm{pH}$ value when aruana grass was fully replaced by gliricidia. This result possibly indicates that gliricidia presents a greater WSC content compared with aruana grass, as well as possibly had higher production of lactic acid. Indeed, the main substrate for production of organic acids are WSC, although some microorganisms present in the silo are able to grow using other sources of energy (Pahlow et al., 2003). The fact that some legumes exhibit greater WSC contents than grasses (especially tropical grasses) is known and reported in the literature (Waldo and Jorgensen, 1981; McDonald et al., 1991). Our results are in agreement with those reported by Oduguwa et al. (2013), in which the inclusion of gliricidia reduced the $\mathrm{pH}$ values in cassava silages.

However, all silages exhibited high $\mathrm{pH}$ values (above 4.8), which may be a problem to control important spoilage microorganisms in farm conditions, such as Listeria spp. and Clostridium spp. (Ryser et al., 1997; Schocken-Iturrino et al., 2005), which are pathogens and can cause diseases in animals and humans (Beuchat and Ryu, 1997). Furthermore, Clostridium species can increase the ammonia-N content in the silage due to the fermentation of amino acids when the $\mathrm{pH}$ value is high (Charmley, 2001), specifically above 4.2 (Pahlow et al., 2003) and increases in DM and energy losses may be expected, as well as reduction in the nutritive value of the silage (McDonald et al., 1991).

Additionally, the lower $\mathrm{pH}$ value recorded in the silages with the replacement of aruana grass by gliricidia should support greater LAB counts at the expense of other microorganisms, such as yeasts, molds, and enterobacteria, which are responsible for increasing DM losses due to heterofermentative fermentation and lowering the efficiency to preserve energy (Muck, 2010). However, as previously reported, this did not occur in the present study. Consequently, there was no difference between the treatments in terms of DM recovery. On the other hand, all silages showed considerable losses during the fermentation process compared with other grass silages produced in mini-silos (Zopollatto et al., 2009). The main cause for this result is associated with the elevated effluent losses, which are a consequence of the low DM content at ensiling (below $280 \mathrm{~g} \mathrm{~kg}^{-1}$ as fed). It is known that effluent production is also one of the main causes of reductions of the silage quality (McDonald et al., 1991). However, to produce silages in farm conditions, an alternative to improve this situation could be the use of additives (e.g., pelleted citrus pulp) or wilting, both aiming to increase the DM content to improve the fermentative process and reduce the DM losses (Bergamaschine et al., 2006).

Gliricidia sepium is a legume, and it is expected therefore that the inclusion of this forage in silages will linearly increase the $\mathrm{CP}$ content and reduce the NDF content of tropical-grass silages (Simons and Stewart, 1994). A possible explanation for these results is that the carbohydrate components of tropical forages have very low solubility (cell-wall components), with low rates of degradation by rumen microorganisms, in addition to higher contents of indigestible NDF compared with other temperate forages or legumes (Dewhurst et al., 2003). Moreover, legumes exhibit greater nitrogen solubility compared with tropical forages (Brown and Pitman, 1991). As a consequence of the differences described above, we observed increases in the IVDMD coefficients of the silages with the addition of gliricidia because the NDF content is negatively correlated with the in vitro digestibility (Van Soest et al., 1994). It is noteworthy that legume cell-walls become more lignified and less digestible with advancing maturity stages, but legumes maintain a higher rate of cell-wall digestion compared with tropical forages (Van Soest et al., 1994). The results of the present study reinforce the idea that the digestibility of low-quality feeds can be increased by the addition of legume leaves (Simons and Stewart, 1994).

Our results reinforce the benefits that grass silages obtain with the inclusion of gliricidia, such as improvement of the fermentation process, reduction of NDF, and increases in the DM digestibility, reported in previous studies (Tjandraatmadja et al., 1994; Kato et al., 2006; Oduguwa et al., 2013).

In the present study, we observed that the best results were obtained with the ensilage of gliricidia alone, which agrees with Man and Wiktorsson (2002), who reported that gliricidia can be well preserved by common ensiling methods without the use of additives. However, gliricidia is a legume species that can grow to a large size (i.e., trees) and become difficult to manage, particularly in relation to the harvest process for ensiling. Therefore, the ensiling 
of gliricidia alone is not recommended (Cabral Jr. et al., 2007). Similar to many high-protein legumes, this type of foliage can be difficult to ensile successfully because it tends to present a high buffering capacity and a low DM content (McDonald et al., 1991). Thus, the ensilage of gliricidia with other forages is necessary to ensure a large volume of ensiled mass (e.g., from grass) associated with the improvement of silage quality (i.e., from gliricidia).

After the silos were opened, the LAB and total bacteria counts exhibited a very different response pattern among the silages, but the population of yeast and mold increased during aerobic exposure. Usually, an overgrowth of yeasts (first microorganism responsible for spoiling the silages) and molds during the feedout phase is expected, as these microorganisms use lactic acid and residual WSC as substrates for growth, which consequently leads to an increase in the temperature during the period of aerobic exposure (McDonald et al., 1991; Wilkinson and Davies, 2012). Consequently, the balance between the rate of heat production by microbial activity and heat loss is increased, which is directly related to the oxidation of DM, causing losses in the form of carbon dioxide $\left(\mathrm{CO}_{2}\right)$, resulting in a decrease in the nutritive value (Wilkinson and Davies, 2012). Furthermore, the action of spoilage microorganisms after silo opening is potentiated under tropical conditions, and it is impossible to control the temperature (Kim and Adesogan, 2006). The silage composed of $50 \%$ aruana grass and gliricidia exhibited lower yeast and mold counts during aerobic exposure. However, the silages' temperatures were relatively constant during the period of aerobic exposure, but we found that the disruption of stability occurred at different times.

Conceptually, the stability breakage occurs when the temperature of the silages exceeds the ambient temperature by $2{ }^{\circ} \mathrm{C}$ after exposure to air (Kung et al., 2007). The assay to test the aerobic stability in this study was conducted at ambient temperature, and reduction of the ambient temperature was the main reason for the disruption of stability in the silages, rather than the increase in silage temperatures caused by the action of spoilage microorganisms (Figure 3). Conversely, although the control of the ambient is not the same compared with trials carried under room with controlled temperature, the evaluation of the aerobic stability in silages in ambient temperature is more accurate to estimate the spoilage of silages in the field (Jobim et al., 2007). However, it is clear that the addition of gliricidia (100\%) improved silage characteristics after silo opening, for example, by reducing the maximum $\mathrm{pH}$ values, which can be indicative of deterioration caused by spoilage microorganisms (Wilkinson and Davies, 2012).
Similarly, during all time of aerobic exposure, the silages composed of 75 and $100 \%$ gliricidia displayed lower $\mathrm{pH}$ values, although the values increased in each treatment after $72 \mathrm{~h}$. Silages composed of legumes alone with low DM are typically more resistant to aerobic deterioration than other silages (e.g., cereals and grass) due to lower growth of yeasts and molds (Weinberg et al., 1993). Conversely, it is important to say here that even though the silage composed of $50 \%$ aruana grass and gliricidia exhibited lower yeast and mold counts during aerobic exposure, the lowest values of maximum $\mathrm{pH}$ were observed in the silages composed of 75 and $100 \%$ gliricidia because the initial $\mathrm{pH}$ values recorded in these silages were lower at silo opening.

We observed that the silage composed of aruana grass alone and with 25 or $50 \%$ gliricidia was more unstable after silo opening. In other words, the addition of a small amount of gliricidia reduces aerobic stability by improving the silage quality of aruana grass. The results of this study are in agreement with those of Barbosa et al. (2011), who observed lower aerobic stability in corn silages produced under tropical conditions with the addition of 10 or $15 \%$ soybean. Conversely, the higher aerobic stability observed for gliricidia silage exclusively is in line with the results reported by O'Kiely and Muck (1992), who found greater stability of lucerne silages compared with corn silage during aerobic exposure.

Under farm conditions, the obtained aerobic stability results indicate that silages with a higher stability, associated with lower occurrences of yeasts and molds, maintain the nutritional and sanitary characteristics observed at silo opening for a longer period. Likewise, more unstable silages must be rapidly removed from silos due to the great reduction of the nutritive value during aerobic exposure under tropical conditions.

Overall, the microbial profile, fermentation, nutritive value, and aerobic stability of the silages responded positively when aruana grass was replaced by gliricidia, which is in agreement with several studies (Tjandraatmadja et al., 1993a,b; Cabral Jr. et al., 2007). Although the wilting of gliricidia may become difficult on farms, the replacement of aruana grass by gliricidia at least by $52.2 \%$ (value estimated through the equations) clearly improved the silage quality, and its use should be considered an alternative.

\section{Conclusions}

We recommended the replacement of approximately $75 \%$ of aruana grass by gliricidia as an alternative to improve the fermentation process, nutritive value, and aerobic stability of tropical grass silages.

R. Bras. Zootec., 44(7):231-239, 2015 


\section{References}

AOAC - Association of Official Analytical Chemistry. 1996. Official methods of analysis. 16th ed. AOAC, Washington, DC, USA.

Barbosa, L. A.; Rezende, A. V.; Rabelo, C. H. S.; Rabelo, F. H. S. and Nogueira, D. A. 2011. Aerobic stability of corn and soybean silage mixed at different ratios. ARS Veterinaria 27:255-262.

Bergamaschine, A. F.; Passipiéri, M.; Veriano Filho, W. V.; Isepon, O. J. and Correa, L. A. 2006. Qualidade e valor nutritivo de silagens de capim-marandu ( $B$. brizanth $\mathrm{cv}$. Marandu) produzidas com aditivos ou forragem emurchecida. Revista Brasileira de Zootecnia 35:1454-1462.

Beuchat, L. R. and Ryu, J. H. 1997. Produce handling and processing practice. Emerging Infections Diseases 3:459-465.

Brown, W. F. and Pitman, W. D. 1991. Concentration and degradation of nitrogen and fibre fractions in selected tropical grasses and legumes. Tropical Grassland 25:305-312.

Cabral Jr., C. R.; Miranda, E. C.; Pinheiro, D. M.; Guimarães, I. G.; Andrade, M. V. M. and Pinto, M. S. C. 2007. Short communication: Fermentative dynamic of Gliricidia sepium silages. Archivos de Zootecnia 56:249-252.

Charmley, E. 2001. Towards improved silage quality - A review. Canadian Journal of Animal Science 81:157-168.

Copani, G.; Ginane, C.; Le Morvan, A. and Niderkorn, V. 2014. Bioactive forage legumes as a strategy to improve silage quality and minimise nitrogenous losses. Animal Production Science 54:1826-1829.

Costa, C. X.; Muniz, E. N.; Sá, C. O.; Sá, J. L.; Rangel, J. H. A. and Farias, I. L. 2007. Efeito da substituição parcial da silagem de milho por silagem de gliricidia sobre o desempenho de cordeiras Santa Inês alimentadas em confinamento. In: Anais do 3o Simpósio Internacional sobre Caprinos e Ovinos de Corte. João Pessoa, PB, Brasil.

Costa, J. H. C.; Hotzel, M. J.; Longo, C. and Balcao, L. F. 2013. A survey of management practices that influence production and welfare of dairy cattle on family farms in southern Brazil. Journal of Dairy Science 96:307-317.

Dewhurst, R. J.; Evans, R. T.; Scollan, N. D.; Moorby, J. M.; Merry, R. J. and Wilkins, R. J. 2003. Comparison of grass and legume silages for milk production. 2. In vivo and in sacco evaluations of rumen function. Journal of Dairy Science 86:2612-2621.

Filya, I. 2003. The effect of Lactobacillus buchneri and Lactobacillus plantarum on the fermentation, aerobic stability, and ruminal degradability of low dry matter corn and sorghum silages. Journal of Dairy Science 86:3575-3581.

Gerdes, L.; Mattos, H. B.; Werner, J. C.; Colozza, M. T.; Santos, L. E.; Cunha, E. A.; Bueno, M. S. and Schammass, E. A. 2005. Forage canopy characteristics and forage accumulation in irrigated Aruana grass pastures or over sown with a mixture of winter forage species. Revista Brasileira de Zootecnia 34:1088-1097.

Jobim, C. C.; Nussio, L. G.; Reis, R. A. and Schmidt, P. 2007. Avanços metodológicos na avaliação da qualidade da forragem conservada. Revista Brasileira de Zootecnia 36:101-119.

Kato, H.; Bareeba, F. B.; Ebong, C. and Sabiiti, E. N. 2006. Ensiling characteristics and milk producing capacity of browse/maize forage mixtures. Livestock Research for Rural Development 18(6). Available at: <http://www.cipav.org.co/lrrd//rrd18/6/kato18085.htm> Acessed on: Oct. 10, 2014.

Keady, T. W. J.; Kilpatrick, D. J.; Mayne, C. S. and Gordon, F. J. 2008. Effects of replacing grass silage with maize silages, differing in maturity, on performance and potential concentrate sapring effect of dairy cows offered two feed value grass silages. Livestock Science 119:1-11.
Kim, S. C. and Adesogan, A. T. 2006. Influence of ensiling temperature, simulated rainfall, and delayed sealing on fermentation characteristics and aerobic stability of corn silage. Journal of Dairy Science 89:3122-3132.

Kung, L., Jr.; Grieve, D. B.; Thomas, J. W. and Huber, J. T. 1984. Added ammonia or microbial inoculant for fermentation and nitrogenous compounds of alfalfa ensiled at various percents of dry matter. Journal of Dairy Science 67:299-306.

Kung, L., Jr.; Schimidt, R. J.; Ebling, T. E. and Hu, W. 2007. The effect of Lactobacillus buchneri 40788 on the fermentation and aerobic stability of ground and whole high-moisture corn. Journal of Dairy Science 90:2309-2314.

Man, N. V. and Wiktorsson, H. 2002. Effect of molasses on nutritional quality of cassava and gliricidia tops silage. Asian-Australasian Journal of Animal Science 15:1294-1299.

McDonald, P.; Henderson, A. R. and Heron, S. J. E. 1991. The biochemistry of silage. 2nd ed. Chalcombe Publications, Abersytwyth, U.K.

Millen, D. D.; Pacheco, R. D. L.; Arrigoni, M. D. B.; Galyean, M. L. and Vasconcelos, J. T. 2009. A snapshot of management practices and nutritional recommendations used by feedlot nutritionists in Brazil. Journal of Animal Science 87:3427-3439.

Moon, N. J. 1983. Inhibition of the growth of acid tolerant yeasts by acetate, lactate and propionate and their synergistic mixtures. Journal of Applied Bacteriology 55:453-460.

Muck, R. E. 2010. Silage microbiology and its control through additives. Revista Brasileira de Zootecnia 39(supl. especial):183-191.

Oduguwa, B. O.; Oni, A. O.; Arigbede, O. M.; Adesunbola, J. O. and Sudekum, K. H. 2013. Feeding potential of cassava (Manihot esculenta Crantz) peels ensiled with Leucaena leucocephala and Gliricidia sepium assessed with West African dwarf goats. Tropical Animal Health and Production 45:1363-1368.

O'Kiely, P. and Muck, R. E. 1992. Aerobic deterioration of Lucerne (Medicago sativa) and Maize (Zea mays) silages Effects of yeasts. Journal of the Science of Food and Agriculture 59:139-144

Pahlow, G.; Muck, R. E.; Driehuis, F.; Oude-Elferink, S. J. W. H. and Spoelstra, S. F. 2003. Microbiology of ensiling. p.31-93. In: Silage science and technology. Buxton, D. R.; Muck, R. E. and Harrison, J. H., eds. American Society of Agronomy, Madison, WI.

Pompeu, R. C. F. F.; Cândido, M. J. D.; Lopes, M. N.; Gomes, F. H. T.; Lacerda, C. F.; Aquino, B. F. and Magalhães, J. A. 2010. Morphological characteristics of Aruana grass under different nitrogen levels. Revista Brasileira de Saúde e Produção Animal 11:1187-1210.

Rangel, J. H. A.; Muniz, E. N. and Sá, C. O. 2011. Implantação e manejo de legumineira com gliricídia (Gliricidia sepium). Circular técnica No. 63. Embrapa, Aracaju.

Ruppel, K. A.; Pitt, R. E.; Chase, L. E. and Galton, D. M. 1995. Bunker silo management and its relationship to forage preservation on dairy farms. Journal of Dairy Science 78:141-153.

Ryser, E. T.; Arimi, S. M. and Donnelly, C. W. 1997. Effects of $\mathrm{pH}$ on distribution of Listeria Ribotypes in corn, hay, and grass silage. Applied and Environmental Microbiology 63:3695-3697.

Santos, E. M.; Zanine, A. M.; Ferreira, D. J.; Oliveira, J. S.; Pereira, O. G.; Cecon, P. R.; Edvan, R. L. and Vasconcelos, W. A. 2009. Chemical composition and dry matter in situ degradability of arboreal legumes from Brazilian Semi-Arid region. Archives of Veterinary Science 14:96-102.

Schocken-Iturrino, R. P.; Reis, R. A.; Coan, R. M.; Bernardes, T. F.; Panizzi, R. C.; Poiatti, M. L. and Pedreira, M. S. 2005. Chemical and microbiological changes of Tifton 85 grass silage after silos opening. Revista Brasileira de Zootecnia 34:464-471. 
Simons, A. J. and Stewart, J. L. 1994. Gliricidia sepium - a multipurpose forage tree legume. p.30-48. In: Forage tree legumes in tropical agriculture. CAB International, Wallingford, UK.

Tilley, J. M. A. and Terry, R. A. 1963. A two stage technique for the in vitro digestion of forage crops. Journal of the British Grassland Society 18:104-111.

Tjandraatmadja, M.; MacRae, I. C. and Norton, B. W. 1993a. Effect of the inclusion of tropical tree legumes, Gliricidia sepium and Leucaena leucocephala, on the nutritive value of silages prepared from tropical grasses. Journal of Agricultural Science 120:397-406.

Tjandraatmadja, M.; MacRae, I. C. and Norton, B. W. 1993b. Digestion by sheep of silages prepared from mixtures of tropical grasses and legumes. Journal of Agricultural Science 120:407-415.

Tjandraatmadja, M.; Norton, B. W. and Mac Rae, I. C. 1994. Ensilage of tropical grasses mixed with legumes and molasses. World Journal of Microbiology and Biotechnology 10:82-87.
Van Soest, P. J.; Robertson, J. B. and Lewis, B. A. 1991. Methods for dietary fiber, neutral detergent fiber, and non-starch polysaccharides in relation to animal nutrition. Journal of Dairy Science 74:3583-3597.

Van Soest, P. J. 1994. Nutritional ecology of the ruminant. 2nd ed. Cornell University, Ithaca.

Waldo, D. R. and Jorgensen, N. A. 1981. Forages for high animal production: nutritional factors and effects of conservation. Journal of Dairy Science 64:1207.

Weinberg, Z. G.; Ashbell, G.; Hen, Y. and Azrieli, A. 1993. The effect of applying lactic acid bacteria at ensiling on the aerobic stability of silages. Journal of Applied Bacteriology 75:512-518.

Wilkinson, J. M. and Davies, D. R. 2012. The aerobic stability of silage: key findings and recent developments. Grass and Forage Science 68:1-19.

Zopollatto, M.; Daniel, J. L. P. and Nussio, L. G. 2009. Aditivos microbiológicos em silagens no Brasil: revisão dos aspectos da ensilagem e do desempenho animal. Revista Brasileira de Zootecnia $38: 170-189$. 